Blaikie, Evi. "Loránt, Endre. 2016. A budapesti papagáj ('The Budapest Parrot') (trans. Zsuzsa Mihályi). Budapest: Kijárat. 264 pp. (originally published as: Lorant, André. 2006. Le Perroquet de Budapest, Une enfance revisitée ['The Parrot - A Budapest Childhood Revisited']). Paris: Viviane Hamy. 281 pp.); Lorant, André. 2017. Fugato. Paris: Cohen \& Cohen. 263 pp." Hungarian Cultural Studies. e-Journal of the American Hungarian Educators Association, Volume 10 (2017) DOI: 10.5195/ahea.2017.285

\title{
Loránt, Endre. 2016. A budapesti papagáj ('The Budapest Parrot') (trans. Zsuzsa Mihályi). Budapest: Kijárat. 264 pp. (originally published as: Lorant, André. 2006. Le Perroquet de Budapest, Une enfance revisitée ['The Parrot - A Budapest Childhood Revisited']). Paris: Viviane Hamy. 281 pp.); Lorant, André. 2017. Fugato. Paris: Cohen \& Cohen. 263 pp.
}

\section{Reviewed by Evi Blaikie*, Freelance Writer}

In his 2006 memoir Le Perroquet de Budapest, Une enfance revisitée ['The Parrot - A Budapest Childhood Revisited'], André Lorant, a professor of French Literature specializing in the works of Balzac at the University of Paris, returns in 1998 for a brief visit to Budapest, the place of his birth whence he escaped, at age twenty six, during the 1956 Hungarian Revolution. Lorant's memoir appeared in Hungarian a decade later, and then, a year later, it was followed by Fugato, a novelized adaptation of the tumultuous life of the author, where his alterego is called Carlo. Lorant's childhood and youth in Hungary encompass the period of World War II and the Holocaust, and then the ensuing Soviet occupation. These momentous historical events are the lenses through which he views Budapest, his family, his teachers, his friends and his enemies. At times it seems that he attempts to make peace with this past and exorcize the traumas he suffered in Hungary but if so then he hardly achieves his goal, and this comes through in the general bitter tone that governs most of this memoir and casts a shadow over Lorant's own self-image, despite the otherwise lively fullness and rich detail of this book. Rather than a straightforward and linear autobiography, this book is a series of memories evoked by the author's wanderings about the city, where certain buildings, churches, parks and streets remind him of particular events, people, feelings, pieces of music and his long buried longings. Consequently the parts of the book are not chronological, with the reminiscences leaping around, often in a stream-of-consciousness style, from Lorant's early memories, to the death of his father, to his grandparents, then back to his own school life, to his sexual experiences, to his friends and enemies in his early life, and to the humiliations he suffered during the Nazi occupation and the ensuing communist regime in his homeland.

From the very first chapter, "A Wicked Stepmother Rather than a Mother," with "mother" meaning "Motherland," the author rails against the Hungary of his youth, speaking of his past homeland as "hated, feared and loved" (25) and accusing it of perfidy, cruelty and cowardice.

*eblaikie0@gmail.com

$($ (c) $)$ EY

ULIS D-Sorke 
Blaikie, Evi. "Loránt, Endre. 2016. A budapesti papagáj ('The Budapest Parrot') (trans. Zsuzsa Mihályi). Budapest: Kijárat. 264 pp. (originally published as: Lorant, André. 2006. Le Perroquet de Budapest, Une enfance revisitée ['The Parrot - A Budapest Childhood Revisited']). Paris: Viviane Hamy. 281 pp.); Lorant, André. 2017. Fugato. Paris: Cohen \& Cohen. 263 pp." Hungarian Cultural Studies. e-Journal of the American Hungarian Educators Association, Volume 10 (2017) DOI: 10.5195/ahea.2017.285

His rage is palpable, yet by the end of the book he discloses that he also feels an "obscure nostalgia for [his] ancestral Hungary" (273); still, at the end of his visit Lorant eagerly returns to his beloved and adopted home, Paris. Already in the first chapter he establishes that he comes from a family that had money and position, and that he had a Catholic upbringing, but other than that he knows very little of his family's history; and if he had hopes that once back in Budapest he could find out more in local archives, to his dismay he realizes that no such archives are available. Yet, he does know that his maternal grandfather was a member of the elite Automobile Club of the Kingdom of Hungary, which, so he remembers, had a select membership of "Great Industrialists" (33-34). The family of this grandfather was one of great landowners about whom Lorant heard that they had founded a home for blind Jews; thus, gradually, the revelation that the author comes from an assimilated or converted Jewish family sneaks into his narrative. For example, he seems to remember that his paternal grandparents claimed to be third-generation Christians (16). This background can explain why he knows so little about Judaism, since his memories are of kneeling in prayer, attending a Catholic school, celebrating Christmas and carrying a crucifix in his pocket (156). In addition, he often refers to several of his friends and acquaintances scornfully as "the little Jew" (46, 47, 63, 80), but, interestingly, as the memoir unfolds he begins to include himself, too, in that category (161). One way or another, in 1944, two months after the death of his father, his helpless mother, his younger sister and he all have to move into one of Budapest's "Jewish houses," where those deemed as Jews by the Nazi racial laws, including assimilated and converted Jews, and even many born as Christians, were now crowded together.

Lorant's mother was "of a good family," and had been educated in Switzerland, meaning she was wealthy, spoiled, naive, and in love with the French language and culture, a trait she managed to pass on to her son (17). He goes on to say that he cannot figure out how or why she married the man who was to be his father, whom, according to their son, she "adored" while he kept cheating on her (171). Shortly before the German occupation of Hungary in March 1944 his father died, leaving the mother a helpless widow at the age of thirty seven. And if all this were not enough, she is also sent to a women's munkaszolgálat ['labor service'] unit in Budapest but is luckily released after three weeks thanks to a Swedish schutzpass ['order of protection'] procured for her. This experience sends her totally over the edge, to the point that afterward in the "Jewish House" she cannot grasp her status and situation, nor can she do so later under communism, so that in a kind of "Stockholm syndrome" mental condition she even "flirts" with, i.e., partly accepts, Nazi and later communist ideology (126).

The author refers to his father as a failed engineer turned inventor who made a very advantageous marriage to his mother, whose substantial dowry of thousands of acres of cultivated land he controlled, and then had the family fortune sold and converted into an apartment-building construction project. At that time, just before the Nazi takeover of Germany and Austria, it would have been much wiser to send the money abroad, yet in spite of the father's bad decisions and even after his untimely death, the family still had some substantial goods for selling after the war but, due to the mother's incompetence in business dealings, they eventually sold their belongings for a much lower price than their real value. Given his mother's inability to deal with life, Lorant becomes the family caretaker and he even eschews moving out of Hungary with his new, first wife so as not to abandon his mother. 
Blaikie, Evi. "Loránt, Endre. 2016. A budapesti papagáj ('The Budapest Parrot') (trans. Zsuzsa Mihályi). Budapest: Kijárat. 264 pp. (originally published as: Lorant, André. 2006. Le Perroquet de Budapest, Une enfance revisitée ['The Parrot - A Budapest Childhood Revisited']). Paris: Viviane Hamy. 281 pp.); Lorant, André. 2017. Fugato. Paris: Cohen \& Cohen. 263 pp." Hungarian Cultural Studies. e-Journal of the American Hungarian Educators Association, Volume 10 (2017) DOI: 10.5195/ahea.2017.285

Lorant writes about his parents and grandparents and about his relationship with them while often using ironic understatements that reveal how different his family and upbringing were compared with those of others of his generation. His descriptions of his childhood experiences portray both his parents as lacking parenting skills and understanding of children. For example, once his father, who had a definite tendency toward sadism, beat him with a leather belt after he caught him kissing his mother while she was asleep. Another example is his sister's feeling of envy of her friend whom she sees climbing, quite naturally, into her father's lap, which the sister could never even dream of (171). This same father, though, also introduced his son to the world and to the love of music, which later became a strong part of the son's life, and about which he writes at great length and with great passion. As toward his parents, the author also remains critical and bitter toward many of his and his family's relatives and acquaintances, at times delving into their private lives; but some of them he does remember with gratitude, such as his childhood friend Tivadar Puskás who stood by him when he had to wear the "infamous yellow star," or his piano teacher Dody (a granddaughter of the founder of the famous Budapest Gerbeaud Café family), who protected him from his classmates' nasty anti-Semitic remarks and even came to his house to give him private piano lessons when Jews were no longer allowed to go out freely $(26,63)$.

Oddly, even though some of his family members were deported and killed, Lorant sounds more indignant and resentful about the treatment he and his family received from the post-war communists than from anti-Jewish persecutors during the Holocaust. Although he forcefully condemns any comparisons of the Holocaust to other massacre events in history, it nevertheless cannot but come through clearly that for him to be accused of being a "capitalist" under communism seems far worse than being accused as a Christ killer, a "stinking Jew" or even just a "little Jew" earlier on. Communism robbed him of his identity as a person belonging to an elite group but could not rob him of his pride at having once belonged to it. Despite his "capitalist" roots, for some reason that is never explained in the book, he is not only allowed to attend university, from where "capitalists" like him were kept out, but he also receives an assistant teacher's position even though he makes no secret of the fact that he despises communism. No doubt, Lorant is a man of many contradictions. The many humiliations that the author feels he has suffered give rise to two other particular issues in his book. First, he lashes out, sometimes unmercifully, against quite a few of the figures who peopled his early life and about whom he writes in great detail. Second, he describes his memories of his early sexual experiences in particularly graphic, even lewd detail, written as though by an angry adolescent. One wonders if he is not dealing with some abuses that he may have suffered and never dealt with, like, for example, when during Confession an odious priest (perhaps deliberately) misunderstands him and angrily accuses him of having practiced bestiality. Yet, at the same time, he also writes of his fantasies of sex with women submissively "giving themselves" to him (89).

Curiously, in 2017, over a decade after the original publication of his memoir, Lorant published his novel Fugato, in which he appears to have created an alter ego whose life partially recapitulates the experiences he had describes in Le Perroquet de Budapest and most of all his sense of ever being a victim of his surroundings and circumstances. The protagonist of this later work, Carlo, is a late-middle-aged man-of-the-world, a cultured and sophisticated producer of operas, who has an affair with a twenty-two year old violinist. Through Carlo, Lorant once again 
Blaikie, Evi. "Loránt, Endre. 2016. A budapesti papagáj ('The Budapest Parrot') (trans. Zsuzsa Mihályi). Budapest: Kijárat. 264 pp. (originally published as: Lorant, André. 2006. Le Perroquet de Budapest, Une enfance revisitée ['The Parrot - A Budapest Childhood Revisited']). Paris: Viviane Hamy. 281 pp.); Lorant, André. 2017. Fugato. Paris: Cohen \& Cohen. 263 pp." Hungarian Cultural Studies. e-Journal of the American Hungarian Educators Association, Volume 10 (2017) DOI: 10.5195/ahea.2017.285

repeats many and varied sexual fantasies appearing in his memoir, as well as returns to his craving for tenderness and intimacy and his great love of music. For example, in Fugato Carlo asks himself whether his affair with the young violinist will help him "ou bien ce rôle reveillerait-il en lui le garçon de quinze ans qui, inhibé par la religion, couvé par sa mère après le mort de son père, n'avait pas eu de vie d'adolescent" ['or would this role awaken in him the youth of fifteen who, inhibited by religion and overprotected by his mother after his father's death, never experienced the life of an adolescent'] (33). Curiously, the novel even features a brightly colored parrot like the one giving the author's earlier memoir its title; in the novel, though, the bird is not a work of tapestry as in the memoir but is the door-knocker to the house where Carlo finds love with the young musician.

The effects of the Holocaust on its survivors are infinite and run the identity crisis gamut from evoking extreme religious feelings to rabid atheism, from a lifelong to jingoist feelings of Jewish superiority, and from a decade-long fear of admitting one's identity to clannishness and feelings of exclusivity or even to aggressive Zionism. Whatever the effects, no survivor escaped unscathed, and neither did André Lorant. His memoir and novel both testify to the ongoing search of survivors for protection from the suffering of the Holocaust. But sometimes, for reasons they reserve for themselves, survivors turn back to their painful origin and face it whether in peaceful or furious terms, as does Lorant, all in the effort to find some peace of mind. For Lorant, the goal of this quest is symbolized by the bird in his memoir's title, which, as we find out in its closing page, is a softly colored, framed tapestry that his mother embroidered while pregnant with him (280). Therefore, for Lorant the "parrot" stands for being protected, secure and loved in ways that he hardly experienced in his later troublesome life. 